\title{
Orbital Lymphangioma: Case Report and Management Paradigms
}

\section{Linfoma de órbita: relato de caso e paradigmas do manejo clínico}

\author{
Alex Roman ${ }^{1} \quad$ Larissa Bianchini $^{1} \quad$ Bárbara Battistel $^{1} \quad$ Miguel Franzoi Neto $^{1} \quad$ Daniela Schwingel $^{1}$ \\ ${ }^{1}$ Hospital São Vicente de Paulo, Passo Fundo, RS, Brazil \\ Address for correspondence Alex Roman, MD, Hospital São Vicente \\ Arq Bras Neurocir 2017;36:136-140. \\ de Paulo, R. Teixeira Soares, 808, Centro, Passo Fundo, RS, 99010-080, \\ Brazil (e-mail: alexroman_@hotmail.com).
}

\begin{abstract}
Keywords

- orbital lymphangioma

- sildenafil

- orbital tumors

\section{Resumo}

\section{Palavras-chave \\ - linfangioma de órbita \\ - sildenafil}

- tumores de órbita
\end{abstract}

Introduction Lymphangioma is a rare congenital vascular malformation of the head and neck region isolated from the systemic circulation. It has a benign etiology, and represents $1-3 \%$ of all orbital tumors. These hamartomas often present in the pediatric population with a slightly female predilection. They have a lymphocytic composition, and may increase in size with episodes of viral infection, causing proptosis.

Discussion The management of this lesion is controversial, hardly curative, and depends on the clinical presentation. The treatment options include partial surgical resection of the major cyst, needle aspiration, surgical debulking, systemic steroids, sildenafil, intralesional injection of the sclerosing agents, and local radiotherapy.

Case Report In the present report, we describe an uncommon case of lymphangioma in a 6-year-old female who was first submitted to neurosurgery for tumor resection and received sildenafil therapy later, with promising results.

Conclusion The treatment of orbital lymphangiomas remains a controversial topic, and the use of sildenafil along with needle aspiration and microsurgical removal is a viable option of treatment. However, many issues, such as the ideal duration of the therapy, the dosage regimen and the recurrence rate, still remain unclear. Our case report adds promising data on this pathology, even though larger trials are needed to properly elucidate the remaining questions.

Introdução Linfangioma é uma malformação vascular rara congênita da cabeça e da região cervical isolada da circulação sistêmica. Apresenta uma etiologia benigna e representa $1-3 \%$ de todos tumores orbitais. Estes hematomas geralmente se apresentam na população pediátrica com uma pequena predileção pela população feminina. Têm uma composição linfocítica e podem aumentar em tamanho com episódios de infecções virai causando proptose.

Discussão O manejo destas lesões é controverso, dificilmente curativo e depende na apresentação clínica. Opções de tratamento compreende ressecção cirúrgica parcial do cisto de maior volume, aspiração por agulha de punção, redução cirúrgica, received

January 23, 2017

accepted

March 16, 2017

published online

May 31, 2017
DOI https://doi.org/

10.1055/s-0037-1603556.

ISSN 0103-5355.
Copyright (e 2017 by Thieme Revinter

Publicações Ltda, Rio de Janeiro, Brazil

License terms

c) $(\oplus) \$$ 
esteroides sistêmicos, Sildenafil, administração intralesional de agentes esclerosantes, e radioterapia local.

Relato de Caso No presente relato, descrevemos um caso incomum de linfangioma em uma paciente feminina de seis anos de idade, inicialmente submetida a procedimento neurocirúrgica para ressecção tumoral, com posterior terapia com Sildenafil, apresentando resultados promissores.

Conclusão $\mathrm{O}$ tratamento de linfangiomas de órbita permanece um tópico controverso, e o uso de Sildenafil em conjunto com aspiração por agulha de punção e ressecção microcirúrgica é uma opção viável de tratamento. Entretanto, muitas quesitos tais como tempo de terapia, regime de dose e taxa de recorrência permanecem incertos. Nosso relato de caso contribui com dados promissores referente a esta patologia, ainda que ensaios maiores são necessários para elucidação apropriada acerca das questões pendentes.

\section{Introduction}

Lymphangioma is a rare congenital vascular malformation of the head and neck region isolated from the systemic circulation. ${ }^{1}$ It has a benign etiology, and represents $1-3 \%$ of all orbital tumors. ${ }^{2}$ These hamartomas often present in the pediatric population with a slightly female predilection. They have a lymphocytic composition, and may increase in size with episodes of viral infection, causing progressive proptosis. $^{2-4}$ The management of this lesion is controversial, hardly curative, and depends on the clinical presentation. The treatment options include partial surgical resection of the major cyst, needle aspiration, surgical debulking, systemic steroids, sildenafil, intralesional injection of the sclerosing agents, and local radiotherapy. ${ }^{5-7}$ In the present study, we describe an uncommon case of lymphangioma in a 6-year-old female who was first submitted to neurosurgery for tumor resection and received sildenafil therapy later.

\section{Case Report}

A 6-year-old female patient presented to the neurosurgery department referring right eye redness. She did not have any known comorbidities or allergies. The patient's father reported the symptoms had been present for approximately ten months, and had had an insidious and progressive course during this period. Upon examination, the patient's eyelids, extra ocular movement and pupillary, as well as consensual light reflex were preserved, the cornea had no signs of inflammatory reaction, and there was tarsal-conjunctival hyperemia. A magnetic resonance imaging (MRI) exam of the head and orbit revealed a large multiloculated mass lesion, the presence of subtle septations inside the right orbit, inferolateral eyeball displacement, and slight stretch of the optic nerve's extrinsic muscles (- Fig. 1). The lesion partially surrounded the optic nerve, and had dimensions of $3.4 \mathrm{~cm} \mathrm{x}$ $2.2 \mathrm{~cm} \times 3.2 \mathrm{~cm}$. It had no significant contrast enhancement, and an apparently liquid content. The patient was further investigated and submitted to a biopsy of the retro-orbital tissue, which confirmed the diagnosis of lymphangioma. The initial management indication was a microsurgical procedure, with posterior pharmacological therapy. A right modified fronto-orbitozygomatic craniotomy approach was the choice for accessing the orbit, with special attention to roof and lateral wall removal (-Fig. 2). The tumor was properly identified with posterior cystic dissection and removal of the solid component, as well as drainage of the fluid contents of the cystic portions of the lesion. After surgery, hydrocortisone (2.5 $\mathrm{mg} / \mathrm{kg} /$ day for 3 days) and sildenafil were prescribed, initially in a dose of $0.5 \mathrm{~mL} / \mathrm{Kg}$ of body mass weight, taken 3 times a day, later increasing the dose to $1 \mathrm{~mL} / \mathrm{Kg}(2.5 \mathrm{mg} / \mathrm{mL})$ of body mass weight, and then increasing the dose up to $10 \mathrm{mg} 3$ times a day, according to European Medicine Agency (EMA) protocols. The patient evolved satisfactorily in the postoperative period, with preservation of visual acuity and ocular motility, and significant improvement of the right-sided proptosis.

\section{Discussion}

Lymphangiomas display a singular combination of clinical, radiologic and histopathological features. The patients may present with either slowly progressive symptoms, or sudden pain and tumor enlargement precipitated by an acute hemorrhage. ${ }^{8}$ Wright et al ${ }^{1}$ reported that the most prevalent manifestation in patients is mass effect (42\%), followed by hemorrhage (37\%), ocular motility changes (28\%), and proptosis (15\%). In advanced stages of the disease, the patients may also develop ophthalmoplegia and amaurosis. ${ }^{9}$ Histopathologically, the orbital lymphangioma is a cystic noncapsulated lesion with irregular thin-walled vascular channels (- Fig. 3), not proliferative, and with an attenuated endothelial layer and collections of lymphocytes. The cyst is classified as microcystic or macrocystic when it is smaller or greater than $10 \mathrm{~mm}$ in diameter respectively. ${ }^{1}$

The pathogenesis of these tumors remains unclear. Recently, new advances on the understanding of lymphatic biology have suggested the role of lymphangiogenesis dysregulation in the development of this tumor. ${ }^{10}$ Angiopoietin 2, forkhead box protein C2 (FOX C2), lymphatic vessel endothelial hyaluronan receptor 1 (LYVE 1), prospero homeobox 1 (PROX1), 

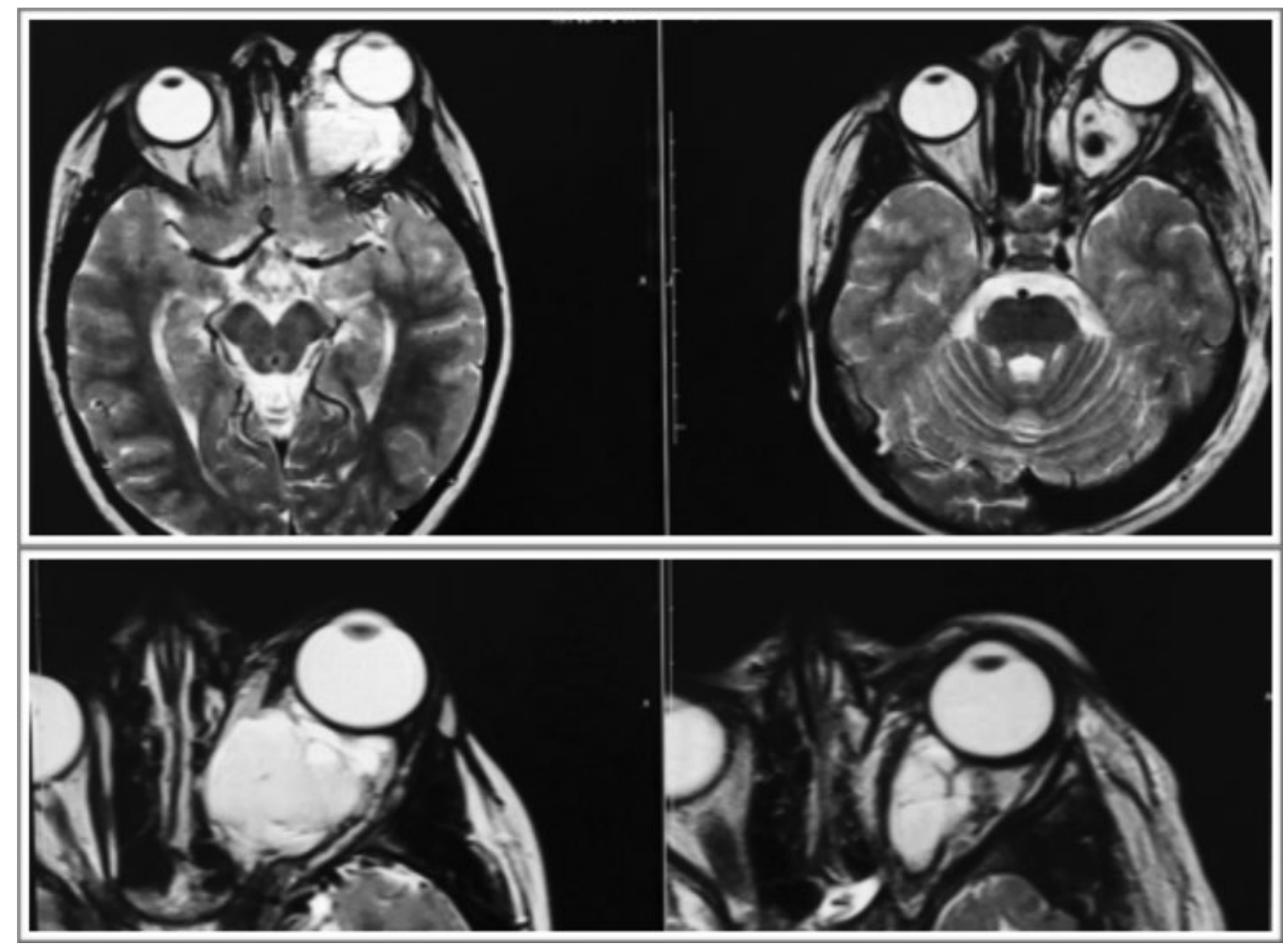

Fig. 1 A and C: preoperative T2-weighted image (T2WI) MRI showing a large left intraorbital multiloculate lesion, with solid and cystic components. B and D: postoperative T2WI MRI showing reduction in volume of the lesion, with diminished proptosis.

podoplanin and vascular endothelial growth factor C (VEGF-C) are some of the gene products critical to lymphatic embryogenesis. ${ }^{11}$ Genetic disorders that possibly correlate with lymphangiomas at different sites have been reported as well. These include neurofibromatosis type $1,^{12}$ Klippel-Trenaunay syndrome, ${ }^{13}$ and tuberous sclerosis complex. ${ }^{14}$ Orbital lymphangioma was related in association with persistent fetal vasculature ${ }^{15}$ and retinal and iris malformations, ${ }^{16}$ among other vascular system abnormalities.

Several imaging methods may suggest the diagnosis of the tumor. Ultrasonography reveals a nonspecific irregular orbital lesion with low internal reflectivity, and has a relevant role mainly in young children. ${ }^{2}$ Contrast-enhanced computed tomography (CT) may show the presence of calcifications within the lesion, and provides useful information on the condition of the orbital wall, enabling the appropriate surgical resection. Magnetic resonance imaging is the best method to evaluate soft tissues and identify cystic fluid levels corresponding to hemorrhages of distinct ages. Old bleedings appear hyperintense in T1- and T2-weighted images, and recent ones appear hypointense. ${ }^{10,11}$

Although there are many treatment modalities for orbital lymphangiomas currently available, there is not a wellestablished one. Furthermore, it is not completely defined if asymptomatic patients should be submitted to any sort of procedure. Spetzler et $\mathrm{al}^{12}$ concluded it is difficult to justify early intervention in asymptomatic patients given the benign biology and high likelihood of recurrence of these lesions. Most authors agree intervention is required when there is visual impairment, severe pain secondary to intraorbital hypertension, repeated hemorrhagic episodes or significant cosmetic deformity. ${ }^{6,7,13}$ Total removal of lymphangiomas without orbit exenteration represents a surgical challenge because they tend to infiltrate into the orbital structures, and may result in severe bleeding during the procedure. Therefore, the goal of the surgery is rather to prolong the diseasefree survival time and offer to the patient an improvement in quality of life. The pterional craniotomy is one of the most-often used routes to access the lesion. Alternatively, a modified frontotemporal orbitozygomatic approach may also be performed, as it was done in our patient. This approach allows for an adequate exposure of the superior and lateral orbital walls and reduces the need for retraction and manipulation of the orbital contents. ${ }^{8,12}$ Other treatment options are subtotal resection ${ }^{14}$, sclerosing agents, as OK- $432^{15}$ or sodium morrhuate, ${ }^{16}$ as well as fractionated $\beta$-irradiation, but this may carry a unwanted risk of optic nerve damage. Moreover, percutaneous needle aspiration can be executed with a significant recurrence rate. ${ }^{6}$ The benefit of sildenafil for the management of cystic lymphatic anomalies was first described by Swetman et al. ${ }^{5}$ This drug inhibits phosphodiesterase-5, and produces vasodilation 

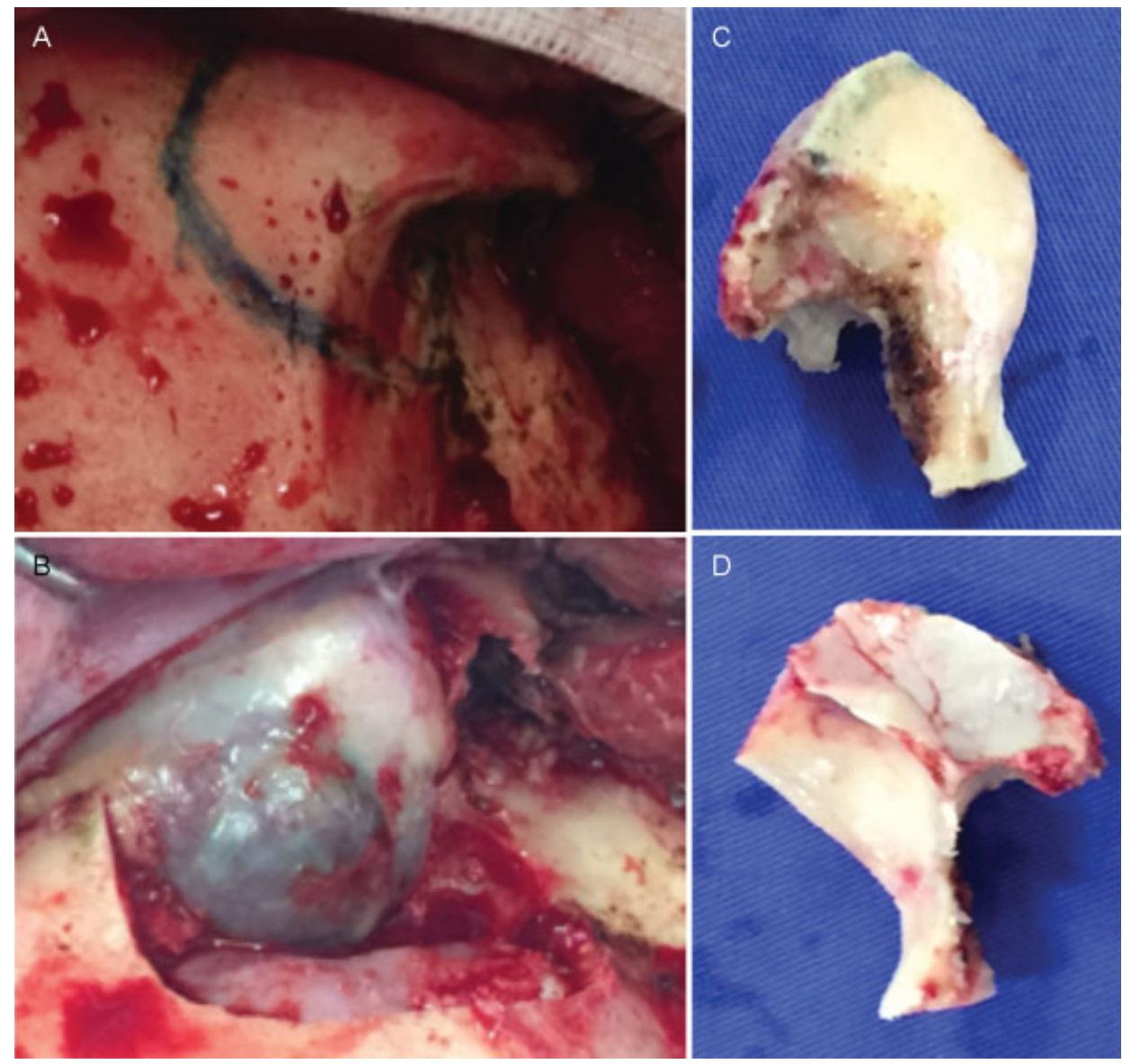

Fig. 2 A and B before and after the removal of the orbital roof and lateral wall, with a modified frontoorbitozygomatic approach. C and D the extension of bony removal may be seen respectively in the outer and inner sides of the bone flap.

followed by relaxation of the smooth muscles, cystic decompression and normalization of endothelial dysfunction, leading to lymphatic vasculature dilation and to the opening of the lymphatic spaces, potentially producing a decrease in lymphangioma volume and, therefore, raising the question about the further potential roles of sildenafil in other vascular pathologies. We found only one other report in the literature of two cases in which sildenafil was used specifically for orbital lymphangiomas. Both case studies showed an improvement in lesion size and symptoms, and had no adverse effects during the follow-up period. ${ }^{17}$

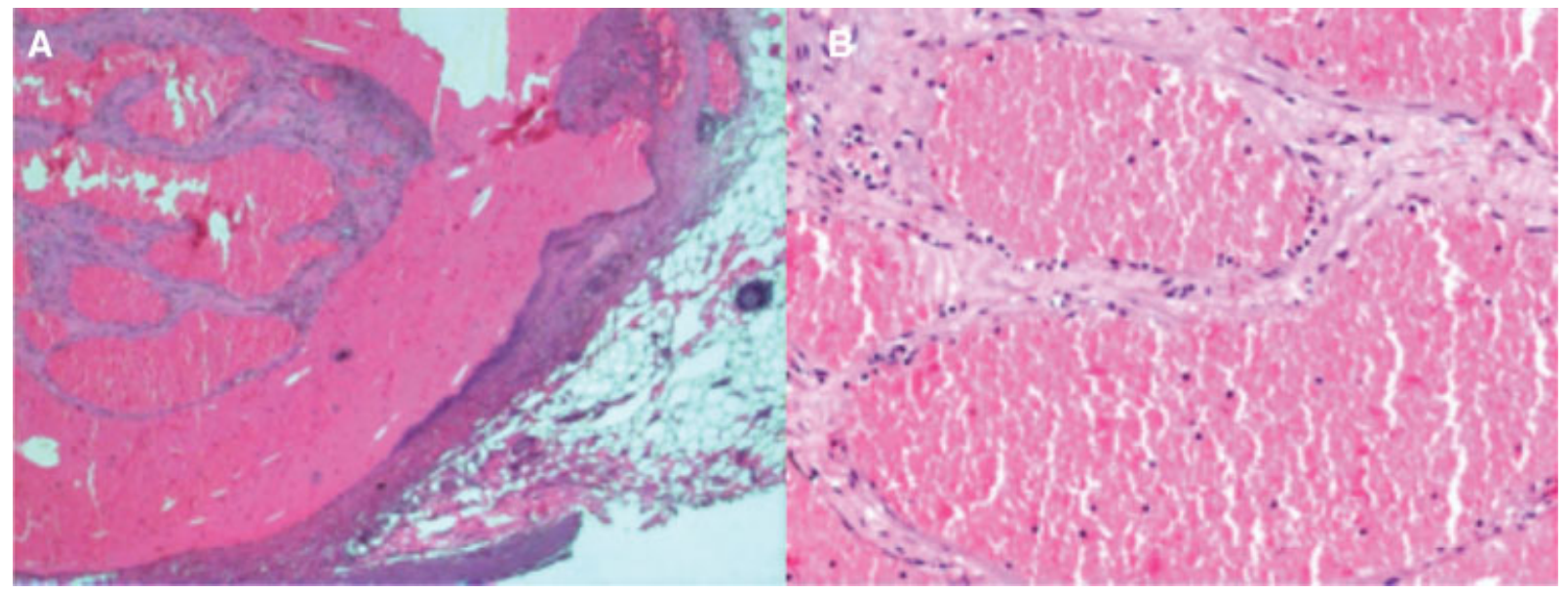

Fig. 3 A and B: histopathology of the infraorbital mass, with hemangyomatose appearance, depicting different sized vessels with blood cells and different staged hemorrhagic content, without any cell atypia. 


\section{Conclusion}

Sildenafil may be a viable non-invasive option for the treatment of orbital lymphangiomas, along with needle aspiration and microsurgical removal. However, many issues, such as the ideal duration of the therapy, the dosage regimen and the recurrence rate still remain unclear. Our case report adds promising data on this tumor, even though larger trials are needed to properly elucidate the remaining questions.

\section{References}

1 Wright JE, Sullivan TJ, Garner A, Wulc AE, Moseley IF. Orbital venous anomalies. Ophthalmology 1997;104(06):905-913

2 Guinto G, Guinto-Nishimura Y. Orbital lymphangiomas. World Neurosurg 2014;81(5-6):708-709

3 Seregard S, Sahlin S. Panorama of orbital space-occupying lesions. The 24-year experience of a referral centre. Acta Ophthalmol Scand 1999;77(01):91-98

4 Alvi S, Kanona H, Penney S, Rothera MP, Bruce IA. Lymphatic malformations. Otorhinolaryngologist 2014;7(02):95-99

5 Swetman GL, Berk DR, Vasanawala SS, Feinstein JA, Lane AT, Bruckner AL. Sildenafil for severe lymphatic malformations. N Engl J Med 2012;366(04):384-386

6 Sekhar LN, Tariq F. Orbital lymphangiomas: surgical treatment and clinical outcome. World Neurosurg 2014;81(5-6):710-711
7 Nassiri N, Rootman J, Rootman DB, Goldberg RA. Orbital lymphaticovenous malformations: Current and future treatments. Surv Ophthalmol 2015;60(05):383-405

8 Simas N, Farias JP. Orbital lymphangiomas: surgical treatment and clinical outcomes. World Neurosurg 2014;81(5-6):842.e5-842.e10

9 Reem RE, Golden RP. Periocular hemangiomas and lymphangiomas. Pediatr Clin North Am 2014;61(03):541-553

10 Bilaniuk LT. Vascular lesions of the orbit in children. Neuroimaging Clin N Am 2005;15(01):107-120

11 Pahwa S, Sharma S, Das CJ, Dhamija E, Agrawal S. Intraorbital Cystic Lesions: An Imaging Spectrum Vol. 44. Elsevier; 2015

12 Russin JJ, Rangel-Castilla L, Kalani MYS, Spetzler RF. Surgical management, outcomes, and recurrence rate of orbital lymphangiomas. J Clin Neurosci 2015;22(05):877-882

13 Pitz S, Dittrich M. Orbital lymphangioma. Br J Ophthalmol 2000; 84(01):124-125

14 Saha K, Leatherbarrow B. Orbital lymphangiomas: a review of management strategies. Curr Opin Ophthalmol 2012;23(05): 433-438

15 Yoon JS, Choi JB, Kim SJ, Lee SY. Intralesional injection of OK-432 for vision-threatening orbital lymphangioma. Graefes Arch Clin Exp Ophthalmol 2007;245(07):1031-1035

16 Kahana A, Bohnsack BL, Cho RI, Maher CO. Subtotal excision with adjunctive sclerosing therapy for the treatment of severe symptomatic orbital lymphangiomas. Arch Ophthalmol 2011;129(08): 1073-1076

17 Gandhi NG, Lin LK, O'Hara M. Sildenafil for pediatric orbital lymphangioma. JAMA Ophthalmol 2013;131(09):1228-1230 